\title{
Postawa ironiczna czołowych aktorów sceny politycznej
}

\section{Ewelina Sudra}

Uniwersytet Łódzki

\begin{abstract}
Abstrakt. Celem artykułu jest analiza wystąpień sejmowych czołowych aktorów sceny politycznej pod względem występowania w nich postawy ironicznej, zarówno od strony werbalnej, jak i niewerbalnej. Do zbadania działań, interakcji, procesów komunikacyjnych oraz interpretacyjnych niezwykle pomocna jest analiza wizualna, czerpiąca z dorobku socjologii interpretatywnej i interakcjonistycznej (Konecki 2005: 43). Wykorzystano ją do opisu i interpretacji reakcji emocjonalnych czołowych postaci sceny politycznej ze względu na zastosowaną ironię. W tym celu wyróżniono następujące role odgrywane przez polityków na sali sejmowej: ironistów, ofiary ironii, obserwatorów ironii.
\end{abstract}

Słowa kluczowe: ironia, socjologia emocji, dyskurs polityczny, emocje, interakcje, Erving Goffman, rytuał ośmieszania

\section{Wstęp}

Ironia w sposób szczególny związana jest z emocjami, a raczej wybuchami emocjonalnymi stanowiącymi nieodzowną część dyskursu politycznego. Ironia komunikuje oprócz treści językowych, także treści emocjonalne. Kultura emocjonalna polityków bogata jest w takie komponenty emocjonalne, jak: sarkazm, ośmiesza- 
nie, ironia. Stanowią one rodzaj „agresji w białych rękawiczkach”. Szczególną cechą ironii ze względu na interakcję komunikacyjną jest zawoalowane wyrażanie postaw emocjonalnych, głównie negatywnych. Opinie wartościujące wyrażane z użyciem ironii nie są oczywiste i nie są zamierzone jako oczywiste. Powszechnie częściej stosowana jest ironia krytyczna (blame-by-praise) w przeciwieństwie do ironii pochwalnej (praise-by-blame) (zob. Bromberek-Dyzman 2011).

Ironia jest traktowana jako p o z o r n a zgoda, pochwała, aprobata, wykorzystywana po to, by pokazać niezgodę, potępienie i dezaprobatę (Passi 1980: 297). To pojęcie trudne do zdefiniowania, o czym świadczy następujące stwierdzenie: „[...] ironia nie może być czymś więcej od tego, czym jest" (ibidem). Najczęściej o ironii mówi się jako kategorii literackiej: „[...] jest to najgłębsza ironia ironii, że zaczyna ona nas nudzić właśnie wtedy, gdy nam ją prezentują stale i wszędzie [...] z ironią rzeczywiście nie ma żartów. Jej efekty mogą dać się odczuć po niewiarygodnie długim czasie" (Alleman 2002: 17). Jednakże kategoria ta ma pochodzenie filozoficzne. To Sokrates był pierwszym „wcieleniem postępowania ironicznego” (ibidem: 18). Potoczne rozumienie ironii jako „ukrytej drwiny, utajonego szyderstwa, złośliwości zawartej w wypowiedzi pozornie aprobującej” (Słownik Języka Polskiego 1969: 240) jest jednak zbyt wąskie i nie oddaje w całości jej istoty korespondującej z założeniami socjologii interpretatywnej i interakcjonistycznej.

Na potrzeby niniejszej analizy przyjmuje się rozumienie ironii jako dwuznacznej gry określającej interakcje między ironistą a osobą wyśmiewaną. Odgrywanie pozy mającej na celu zdefiniowanie siebie i dyskryminację przeciwnika rozgrywa się w konkretnym kontekście, otoczeniu. Ironista posługuje się ironią, by zdemaskować pozę przeciwnika, ujawnić jej wewnętrzną sprzeczność. Ironia ujawnia niekonsekwencję rozmówcy w jego zachowaniu wobec innych oraz piętnuje sposób zachowania, który polega na tym, że ktoś mówi jedno, a robi drugie. Osoba za 
pomocą ironii dąży do uporządkowania relacji z rozmówcą, do zaprzestania przez niego przyjmowania póz i udawania. Ironia jako gra wciąga słuchacza, czy on tego chce czy nie, buduje więź między mówiącym a słuchaczem (Ososiński 2014: 17, 195).

Przedmiotem niniejszej analizy jest postawa ironiczna. Tradycyjna retoryka traktuje ironię w kontekście nastawienia psychicznego jako figurę retoryczną związaną z postawą ironiczną autora, która nie zawsze ujawniać się może w pojedynczych zwrotach. Przez postawę ironiczną autorka rozumie: „świadomość, którą cechuje poczucie kontrastu, sprzeczności między zjawiskami świata wewnętrznego lub zewnętrznego danej jednostki oraz poczucie własnej wyższości ironizującego; przy czym uświadamiana przez jednostkę sprzeczność zostaje podporządkowana określonej idei bądź wizji świata i bytu ludzkiego" (Łaguna 2004: 25). Postawa ironiczna posiada trzy wyznaczniki. Pierwszym jest poczucie sprzeczności zawierające się w doświadczeniu ironizującego podmiotu jako inspiracja, świadomość. Jest ono lokowane na płaszczyźnie społecznej, historycznej, filozoficzno-poznawczej, moralnej. Drugi wyznacznik to poczucie wyższości, które może się kształtować na różnych poziomach nastawienia ironicznego. Związane jest z dążnością do uzyskania przewagi nad przeciwnikiem. Jako ostatni wyznacznik trzeba wymienić intencję podporządkowania doświadczenia pewnej idei, które zdobył podmiot ironizujący i włączenia go do swojego światopoglądu (Łaguna 2004: 28-40). Ironizujący posiada wiele intencji. Po pierwsze, cel jego może mieć charakter dydaktyczny, związany z zamiarem zaangażowania odbiorców w daną tematykę; po drugie, osobie ironizującej zależy na pokonaniu sprzeczności i uzyskaniu wewnętrznej harmonii osobowości; po trzecie, intencją jest samoobrona jednostki, która czuje się zagrożona przez środowisko pragnące narzucić jej określony schemat myślenia (Łaguna 2004: 40-41). Ironia może stanowić oparcie dla jednostki. Jest siłą, która podtrzymuje jednostkę (nawet nieświadomą tego), udaremnia 
atak na nią, troszczy się o nią. W sytuacji gdy ktoś zostanie niesłusznie posądzony, nie musi być tego świadom, bowiem ironia sprawi, że oszczerstwa obciążą tego, kto je sformułował. Ironia pokaże nieczyste sumienie tego, kto oskarżał drugiego, był zdolny rzucać pod czyimś adresem oszczerstwa, mimo że jego zachowanie nie dawało ku temu żadnych podstaw. Ironia ośmiesza przeciwników, chroniąc niejako atakowaną jednostkę przed nimi, staje się jej oparciem (Ososiński 2014: 192-193).

Postawę ironiczną przyjmują politycy w rozmaitych sytuacjach i w wielu debatach. W języku politycznym stosuje się rozliczne zabiegi językowe. Funkcja informacyjna języka nie pełni tutaj głównej roli, lecz do głosu dochodzą funkcje perswazyjna, emotywna i argumentująca. Styl, jakim posługują się politycy, obfituje w liczne środki językowe mające spowodować u odbiorców określone emocje i działania. Działacze polityczni przy użyciu właściwej argumentacji próbują przebić się do podświadomości audytorium, narzucając mu swoją wolę. Ironia jest stosowana w celach polemicznych, ma na celu wzruszać lub pouczać odbiorców. Politycy nadużywają różnych aktów emotywnych, bowiem język emocjonalny o wiele bardziej przekonuje odbiorców niż język pozbawiony emocji, oparty na faktach i merytorycznej argumentacji. Należy jednak dodać, że często język emocjonalny nie jest tożsamy $z$ rzeczywistym stanem emocjonalnym nadawcy. Z manipulowaniem emocjami mamy do czynienia wtedy, gdy nadawca wyraża inną emocję niż ta, którą odczuwa; gdy nadawca nie przeżywa danej emocji, a mimo to ją wyraża (Przyłęcki 2012: 102-114). „Polityka jest ulubioną maską metafizyki, która weszła w fazę ironii” (Graczyk 2004: 101).

Ironia posiada wiele odmian, stopni. Może być bardziej lub mniej rozpoznawalna. Dlatego mówimy o ironii jawnej - gdy sprzeczność jest bardzo widoczna, albo o ukrytej - gdy należy ją dopiero dostrzec, wykryć (Muecke 2002: 62-65). Podstawowym, a zarazem najstarszym rozróżnieniem odmian ironii jest jej po- 
dział na ironię sokratyczną, retoryczną i romantyczną. Pierwsza jest pewną praktyką poznawczą (poszukiwaniem prawdy), przejawia się w grze między mówiącym a słuchaczami - to dyskusja, polemika. Ironia retoryczna z kolei polega na narzuceniu odbiorcom postulowanych ocen i stanowisk, stanowi formę oddziaływania na publiczność. Ironia romantyczna natomiast kształtuje pewną relację między podmiotem mówiącym a jego słowami, ma ona bardziej charakter literacki (Głowiński 2002: 6-13).

Innym podziałem ironii jest podział na ironię werbalną i ironię sytuacyjną. Ironia werbalna stanowi efekt wykorzystywania przez podmiot pewnych technik, wymaga istnienia świadomości i intencji. Natomiast ironia sytuacyjna ujawnia się ze zbiegów okoliczności, jako rezultat pewnych wydarzeń. Obie zawierają jakąś sprzeczność. W ironii werbalnej to autor nam ją ukazuje, konfrontuje z innymi rzeczami, zaś w ironii sytuacyjnej coś samo przyciąga naszą uwagę (Muecke 2002: 46). Analiza słowna wyróżnia ironię humorystyczną i satyryczną. Ta pierwsza to łagodna i dobroduszna ironia, w której przejawia się pobłażliwość ironisty. Druga to ironia złośliwa i ostra, odczuwa się w niej nieprzejednanie satyryka (Passi 1980: 299).

Ze względu na sposób ironizowania wyróżnia się następujące odmiany ironii: bezosobową, samouwłaczającą, naiwną, udramatyzowaną. Istota ironii bezosobowej polega na tym, że odbiorcy koncentrują się na samych słowach, nie ma dla nich znaczenia, kto je wypowiada, ani jakim jest człowiekiem. Należy jednak zwrócić uwagę, iż występuje zasadnicza różnica między tym, co podmiot wypowiada, a tym, co naprawdę myśli. Gdy ironista wprowadza na scenę samego siebie, ale pod przybraną postacią osoby niedouczonej, łatwowiernej, to możemy mówić o ironii samouwłaczającej, której rodzajami są niedomówienia, przesady. Trzecia odmiana, ironia naiwna odznacza się tym, że ironista przedstawia się jako „naiwny głuptas”, który jednak widzi więcej niż pozostali, mądrzejsi od niego. $\mathrm{W}$ ostatnim przypadku, ironii 
udramatyzowanej, ironista całkowicie maskuje swoją tożsamość i ogranicza się tylko do relacji jakiejś ironicznej sytuacji czy zdarzenia. Ironią udramatyzowaną najczęściej posługują się dramaturdzy i powieściopisarze (Muecke 2002: 71-74).

W analizie ironii bardzo ważnym aspektem jest określenie ról, jakie pełnią poszczególni aktorzy. Wyróżnia się: ironistów, obserwatorów ironii i ofiary ironii. Obserwatorzy ironii mogą w pełni rozumieć ironię, zaś ofiary na skutek błędnego przekonania bądź naiwności mogą jej nie uchwycić lub nie zdawać sobie sprawy z tego, że padli ofiarą ironii, co jest szczególnie widoczne przy ironii sarkastycznej (Kaufer 2002: 147). W analizie stosuje się również pojęcia pola napięcia lub strefy gry ironicznej (Doda 2007: 9).

\section{Analiza wystąpień sejmowych - postawa ironiczna}

Analiza dotyczyła wystąpień sejmowych, zarówno od strony werbalnej, jak i niewerbalnej, w kontekście występowania postaw ironicznych. Skupiono się na postaciach Donalda Tuska i Jarosława Kaczyńskiego. Błędne jest przekonanie, że ironia to forma dominująca w wystąpieniach sejmowych. W rzeczywistości więcej jest w nich oskarżeń rzucanych pod adresem politycznych przeciwników, obwiniania się, przerzucania odpowiedzialności i wyciągania na światło dzienne faktów z przeszłości. Oczywiście, te aspekty mogą zostać „ubrane” w ironię, jednakże ani forma wypowiedzi, ani reakcje publiczności, jak również założenia definicyjne nie wskazywały, że mamy do czynienia z zabarwieniem ironicznym. Analizując postawę danej osoby, nie można z całą pewnością orzec, że jest ona ironiczna bądź nie. Istnieje pewna niedookreśloność, wyrażająca się w tym, że dla jednych odbiorców coś okazuje się być ironiczne, a dla drugich niekoniecznie. To, czy dana postawa odczytana zostanie przez odbiorcę jako iro- 
niczna, wynika nie tylko z jego słownej deklaracji, ale również z jego nastawienia i znajomości kontekstu. Poniższy dobór filmów jest wynikiem subiektywnej oceny dokonanej przez autorkę. Spośród dużej puli obejrzanych na YouTube filmów, poddano analizie te, co do których autorka miała pewność wystąpienia $\mathrm{w}$ nich znamion postawy ironicznej u co najmniej jednej postaci. Oto wybrane filmy:

- Kaczyński vs Tusk - Daj Pan spokój, 24.01.2014, opublikowany: 25.01.2014, liczba wejść na YouTube: 53 476 ${ }^{1}$;

- Tusk o Kaczyńskim: Obudził się lider opozycji i prezentuje odwage w spotach, opublikowany: 19.08.2011, liczba wejść na YouTube: 7 508;

- Donald Tusk: Debata o polskiej polityce zagranicznej de facto odbyła się w godzinach..., 15.12.2011, opublikowany: 17.05.2013, liczba wejść na YouTube: 192;

- Kaczyński: Możecie się obstawiać policją. My się nie boimy tego referendum, opublikowany: 30.03.2012, liczba wejść na YouTube: 8741;

\subsection{Kaczyński vs Tusk - Daj Pan spokój}

Debata sejmowa obejmowała wymianę zdań między premierem Donaldem Tuskiem a prezesem PiS Jarosławem Kaczyńskim. Poprzedziła ona głosowanie nad wnioskiem o odwołanie Ministra Zdrowia Bartosza Arłukowicza. Szef rządu zarzucił PiS, że nie broni interesów pacjentów.

Postawa ironiczna Donalda Tuska wyraża się poprzez ośmieszenie jego przeciwnika politycznego, co jest zauważalne w następującym fragmencie wypowiedzi:

1 Liczba wejść na portal YouTube dla każdego filmu została zanotowana 9.06.2014 r. 
Nie trzeba mieć szczególnie potężnego charakteru panie Prezesie, żeby napiąć mięśnie i zacisnąć pięści wobec pielęgniarek.

Donald Tusk podważa autorytet adwersarza, zarzuca mu atak wymierzony w bezbronnych ludzi, jakimi są pielęgniarki, kobiety, które powszechnie uważa się za istoty niewinne i bezbronne. Zadaniem polityka zaś jest nieść pomoc i ratunek bezbronnym osobom, a nie z nimi walczyć.

Postawę ironiczną premiera wzmacniają użyte przez niego zarzuty o charakterze okołomerytorycznym, które jeszcze bardziej ośmieszają Jarosława Kaczyńskiego. Zarzut techniczny ma postać:

Przypominam, jak zachowywat się PiS i jak zachowywało się SLD w czasie pierwszej i tej najbardziej czytelnej konfrontacji w obronie publicznych pieniędzy. To była tzw. sprawa szczepionkowa.

Donald Tusk zarzuca dwóm partiom politycznym (PiS i SLD) naganne zachowanie w "grze” o publiczne pieniądze. To „złe” zachowanie wyrażało się popieraniem nie interesów pacjentów, a koncernów farmaceutycznych. Tej kwestii dotyka zarzut moralny o treści:

Trzeba mieć odrobinę cywilnej odwagi i coś z rycerza w sobie, żeby żeby stanąć po stronie po stronie pacjentów, a nie po stronie koncernów farmaceutycznych.

W powyższym zarzucie premier nawiązuje do etosu rycerza, cnót rycerskich, do których zalicza się odwagę, szlachetność, solidarność, obronę najsłabszych. Wydaje się, iż właśnie ten zestaw cech pozwala politykowi na przestrzeganie i realizację wartości polityczno-moralnych, jakimi są: ład społeczny, pokój, bezpieczeństwo, równość i sprawiedliwość, humanitaryzm, dobrobyt. 
Znajdują one swoje odzwierciedlenie w walce o wolność, równość i sprawiedliwość (Blaszke 1978: 253-254). Zdaniem premiera, Jarosław Kaczyński nie przestrzega kodeksu rycerskiego. Wręcz przeciwnie, wyznaje „odwrotny” kodeks, gdyż nie dość, że nie pomaga pacjentom, to jeszcze sprzymierza się przeciwko nim $\mathrm{z}$ „najsilniejszymi”, czego dotyczy zarzut etyczny:

Idziecie ręka w rękę z najsilniejszymi przeciwko najsłabszym. Na tym polega problem.

Kolejny zarzut, kulturowo-językowy, stanowi puentę odzwierciedlającą paradoksalne zachowanie przeciwnika politycznego:

I okraszacie to okrzykami: Łapcie złodzieja.

Ironia Donalda Tuska jest ironią retoryczną. Buduje ocenę zachowania Jarosława Kaczyńskiego i stara się tym przekonać „publiczność" do swoich racji, narzucić jej swoje stanowisko. Można by powiedzieć, iż cel wystąpienia premiera ma charakter dydaktyczny, związany jest z zaangażowaniem podmiotu w problematykę polityczno-społeczną lub moralno-obyczajową, jaką stanowią kwestie dotyczące resortu zdrowia.

Wyznacznikiem postawy ironicznej wykorzystanej przez Donalda Tuska jest poczucie wyższości, co wyraża się w stwierdzeniu:

Trzeba mieć odrobinę cywilnej odwagi, żeby stanąć przeciwko tym, którzy są uzbrojeni w agencje reklamowe, w lobbystów i w gigantyczne pieniądze, ale to trzeba mieć to coś Panie Prezesie, co charakteryzuje w polskiej polityce niezbyt wielu.

Premier ponownie nawiązuje do odwagi jako cnoty rycerskiej, cechy, która stanowi o przeciwstawieniu się „najsilniejszym”. Wskazuje, iż trzeba mieć dodatkowo „to coś”, czym może się po- 
chwalić niewielu polityków. Między wersami można wyczytać, iż Donald Tusk posiada „cywilną odwagę” oraz „to coś”. Dzięki temu zalicza siebie do niewielkiego grona „wybrańców”. Daje się zauważyć, iż wypowiedź premiera spełnia funkcję perswazyjną. Dyskusja polityczna jest tutaj tak ukierunkowana, aby przekazywała pozytywny wizerunek osoby przemawiającej („ukryty” między wersami) oraz wzbudzała przychylność audytorium dla prezentowanych przez mówcę opinii, a osłabiała pozycję adwersarza (Milkoska-Samul 2013: 170).

Analiza strony werbalnej i niewerbalnej pozwala z łatwością odgadnąć, jakie role przyjmują poszczególne osoby trwającej debaty sejmowej. Donald Tusk jest tu ironistą. Został dopuszczony do głosu w pierwszej części debaty. Eksponując postawę ironiczną, opiera się o mównicę, akcentuje słowa uderzając dłonią lub palcem o blat. Stoi wyprostowany i patrzy przed siebie, czasami kierując głowę w prawą stronę (tam siedzą posłowie PiS). Przy słowach, że trzeba mieć „to coś”, uśmiecha się. Jednakże przy słowach mówiących, iż niewielu posiada „to coś”, ucieka wzrokiem ku swoim notatkom, które leżą na blacie. Opuszcza głowę, co może oznaczać uniknięcie skupienia uwagi, chęć ukrycia emocji (Goffman 1987: 63). Zachowanie to może świadczyć o pewnym zawstydzeniu i/lub skromności i tym samym daniu „publiczności” do zrozumienia, iż on sam tę wyjątkowość posiada. Ofiarą ironii pada Jarosław Kaczyński, gdyż to w głównej mierze do niego oraz jego partii są skierowane słowa. Nie wiadomo, jak zachowuje się prezes PiS przy wymienianych przez premiera zarzutach, gdyż kamera jest wtedy całkowicie skoncentrowana na Donaldzie Tusku. Przy słowach o posiadaniu „tego czegos'” kamera pokazuje Jarosława Kaczyńskiego. Jego twarz nie wyraża żadnych emocji, jest skupiona na słuchaniu, niezmienna. Prezes PiS trzyma jedną dłoń umieszczoną w drugiej, którą głaszcze, co może świadczyć o ważeniu słów przeciwnika. Obserwatorami ironii są wszystkie osoby znajdujące się na sali sejmowej. Ich reakcje są żywe i uzależnione od tego, do której partii przynależą. 
Przy ironicznych słowach Donalda Tuska, członkowie jego partii reagują brawami i śmiechem, zaś ze strony członków PiS dochodzą podniesione głosy niezadowolenia. Sam Donald Tusk manipuluje „publicznością” dodając:

Chcę powiedzieć, że to są... styszycie Państwo jak bardzo, jak żywe reakcje te przykre, prawdziwe słowa wzbudzają szczególnie po stronie PiS-u. Ten sam rejwach, te same emocje rodziły się w szeregach opozycji i wtedy, kiedy przygotowywaliśmy i wprowadzaliśmy ustawę refundacyjną, która miała ustawowo limitować dochody koncernów farmaceutycznych, po to aby chronić polskich pacjentów przed zbyt wysoka... wysokimi wydatkami na leki.

Przechodząc do scharakteryzowania postawy ironicznej Jarosława Kaczyńskiego, można dostrzec pewne znaczące różnice. Prezes PiS ironizuje, wykorzystując do tego pochwałę, jest to ironia przez pochwałę. Pochwała to wyraz pozytywnej opinii na jakiś temat lub opinii dotyczącej danej osoby. Osoba, do której kierowana jest ironia, jeśli jej nie rozpozna, nie uchwyci, staje się jej ofiarą, bez możliwości obrony. Pierwsza pochwała wypowiedziana przez Jarosława Kaczyńskiego ma postać:

Ale to, że jest Pan mistrzem insynuacji, to oczywiście wiem, ale że Pan będzie się tutaj stawiat jako bojownik z lobby, no to muszę się przyznać, że Pan w bardzo ważnej sprawie przekroczył już wszelkie granice, no może nie tyle dobrego smaku, czy tylko tego wszystkiego, co każe o sprawach poważnych mówić poważnie.

Nazywa Donalda Tuska „mistrzem insynuacji”. Samo określenie „mistrz” jest określeniem nacechowanym pozytywnie, oznacza człowieka będącego najlepszym w jakieś dziedzinie. Tą dziedziną w przypadku Donalda Tuska jest jednak „insynuacja”, czyli przypisywanie komuś pewnych działań, myśli, intencji niezgodnych z prawdą. Połączenie tych dwóch słów nie niesie pozytywnego wydźwięku. Kolejna pochwała jest następującej treści: 
Bo tylko w kategoriach kabaretowych Was, Wasz rząd można traktować jako siłę, która walczy z lobby. Wyście stworzyli system polityki, która jest przez politologów nazywana polityką transakcyjną. To jest nazwa sprzed wielu lat i wyście ten system doprowadzili można powiedzieć do perfekcji.

Mamy tu podobną sytuację. Słowem o pozytywnym nacechowaniu jest „perfekcja”, będąca synonimem doskonałości. Natomiast wyrażeniem, które Jarosław Kaczyński przedstawia w negatywnym świetle, jest „polityka transakcyjna”, którą właśnie członkowie PO opanowali i doprowadzili do perfekcji.

Wyznacznikiem postawy ironicznej zastosowanej przez Jarosława Kaczyńskiego jest poczucie sprzeczności, wyrażające się $\mathrm{w}$ następującym stwierdzeniu:

No i jeszcze jedna rzecz, która mnie naprawdę niebywale rozbawiła. Panie Premierze, no jeśli pan mówi o honorze i rycerskości, no, no daj Pan spokój.

Tym zdaniem nawiązuje on do słów Donalda Tuska, który zarzucał mu brak odwagi i rycerskości, by przeciwstawić się koncernom farmaceutycznym. Używając tego sformułowania, podważa cechy Donalda Tuska, daje wszystkim do zrozumienia, iż człowiek, który nie posiada powyższych cech, nie ma prawa o nich mówić, a tym bardziej wytykać ich nieposiadanie komuś innemu.

Zastosowana przez Kaczyńskiego ironia to ironia sokratyczna, polegająca tutaj na poszukiwaniu prawdy, czym jest rycerskość i kto ją przede wszystkim posiada. Należy również stwierdzić, iż celem użycia powyższej ironii była intencja samoobrony przez jednostkę, która czuła się zagrożona narzuconym sposobem myślenia o niej i jej partii.

W tym przemówieniu odwróciły się role głównych aktorów. Tutaj ironistą jest Jarosław Kaczyński. Przy wypowiadaniu pochwał jego głowa jest skierowana w kierunku PO. Często rozkła- 
da ręce i wskazuje palcem w ich stronę. Udaje zdziwienie, marszczy brwi. Uśmiecha się. Przy słowach „jeśli pan mówi o honorze i rycerskości” ręce ma złożone, uśmiecha się. Ofiarą ironii tym razem staje się Donald Tusk. Jego ciało wyraża napięcie. Łokieć trzyma oparty o poręcz siedzenia, ma nieobecne spojrzenie, „zasznurowane" usta. Taką postawę zachowuje również przy słowach Jarosława Kaczyńskiego „daj pan spokój”, jednak zauważalny jest delikatny, twierdzący ruch głowy mogący świadczyć o kpiącym stosunku do przedmówcy. Członkowie PiS stają się głównymi obserwatorami ironii, gdyż tylko ich reakcje słychać na sali. Przy powyższych wypowiedziach prezesa PiS reagują gromkimi brawami i śmiechem.

\subsection{Tusk o Kaczyńskim: Obudzit się lider opozycji i prezentuje odwagę w spotach}

Jest to fragment debaty sejmowej ukazujący krótkie przemówienie lidera PO Donalda Tuska w kontekście odpowiedzi na pytanie „Jak żyć?” zadane przez Jarosława Kaczyńskiego i Grzegorza Napieralskiego.

Postawa ironiczna wyraża się poprzez ośmieszenie. Donald Tusk zauważa, że zarówno Grzegorz Napieralski, jak i Jarosław Kaczyński są wyjątkami, którzy nie wiedzą, „jak żyć”, podczas gdy reszta społeczeństwa doskonale wie. Obaj politycy przeciwstawieni zostają reszcie społeczeństwa. Następujący fragment może stanowić próbę samoobrony lidera PO poprzez akcentowanie faktu, iż Polacy wiedzą "jak żyć” i nie muszą tego pytania zadawać:

Wydaje się, że od kilkunastu dni liderzy dwóch partii opozycyjnych, Panowie Napieralski i Kaczyński tak jakby przestali wiedzieć, jak żyć w Polsce, ale Polacy wiedzą, jak żyć, między innymi dzięki temu, że te krytyczne ostatnie na świecie i w Europie dwa lata przebiegły w Polsce względnie spokojnie. 
W kolejnym fragmencie wypowiedzi premier ponownie nawiązuje do odwagi jako cechy wyróżniającej polityka. Ironizuje na temat odwagi Jarosława Kaczyńskiego, która pozwala mu jedynie na prezentowanie się w spotach reklamowych, w mówieniu, ale nie w działaniu i przeciwstawieniu się realnym problemom:

[...], obudzit się lider opozycji i prezentuje odwagę w spotach telewizyjnych. Wie Pan co Panie prezesie Kaczyński. Ja widziałem niejednego odważnego w spotach i w reklamówkach, ale od przywódcy formacji politycznej wymaga się, żeby trwał na mostku kapitańskim wtedy, kiedy obywatele w wyborach dali mu prawo i szansę sprawowania władzy. Pan uciekł po dwóch latach, mimo że sytuacja wokót i w Polsce i na świecie napawała wszystkich optymizmem, Pan wytrzymał raptem dwa lata.

Co więcej, zarzuca mu tchórzostwo, które jest antonimem słowa „odwaga”. Mamy tutaj do czynienia z ironią retoryczną, gdyż premier próbuje oddziaływać na „publiczność”, narzucić jej swoje poglądy, co szczególnie widać w słowach:

Ale nie sądzę, żeby Pan Kaczyński, czy poseł PiSu yyy który przed chwilą krzyczat, ma prawo takie pytanie zadawać. Miliony Polaków wiedzą jak żyć w Polsce.

Została tu wykorzystana presupozycja semantyczna, realizująca się w przypisaniu Polakom posiadania wiedzy „jak żyć” w Polsce.

W omawianym wystąpieniu widoczne jest także poczucie wyższości, które stanowi wyznacznik postawy ironicznej. Można je dostrzec w słowach:

Naprawdę trzeba mieć mocne nerwy, naprawdę trzeba mieć odwagę nie w spotach tylko w rzeczywistości, żeby sprostać wyzwaniom przed jakimi staje Polska. 
Donald Tusk nawiązuje tutaj ponownie do odwagi, ale podkreśla też posiadanie „mocnych nerwów” jako istotnej cechy, która pozwala wyjść naprzeciw wyzwaniom i problemom. Twierdzi, że odwagę należy wykorzystać dla sprostania kryzysowi, który „nie zna precedensu w ostatnich dwudziestu, trzydziestu latach w wymiarze globalnym i europejskim", a nie prezentować ją tylko w mediach. Skoro lider PO wymienia niezbędne cechy polityka działającego w obecnych ciężkich czasach, wychodzącego naprzeciw współczesnym wyzwaniom, można domniemywać, iż sam uważa się za posiadającego te zalety, bowiem one kwalifikują go do bycia przywódcą. Tego samego zabiegu użył Donald Tusk w swoim wystąpieniu w poprzednim analizowanym filmie (Kaczyński vs Tusk - Daj Pan spokój), tam również wymieniał on pożądane u polityka cechy („odwaga” i „to coś”), zaznaczając jednocześnie, że niewielu może się nimi pochwalić.

Ironistą, postacią pierwszoplanową, jest Donald Tusk. Stoi oparty o mównicę, twarz ma skierowaną w prawą stronę (w stronę posłów PiS). „Cechy prawdziwego polityka” odlicza na palcach. Nic nie wiemy o ofierze ironii, którą jest Jarosław Kaczyński, gdyż kamera ani razu nie została skierowana w jego stronę. Co zaś się tyczy obserwatorów ironii, to aktywni są ci politycy, którzy popierają Donalda Tuska, z ich strony słychać śmiech i oklaski. Zachowania niewerbalne członków PO pełnią funkcję wspierającą i wzmacniającą słowa ich przywódcy.

\subsection{Donald Tusk: Debata o polskiej polityce zagranicznej de facto odbyła się w godzinach....}

Filmik ten zawiera wystąpienie lidera PO w kontekście odpowiedzi na złożenie przez PiS wniosku o wotum nieufności wobec Radosława Sikorskiego. Premier odpierał zarzuty skierowane pod adresem szefa MSZ. Forma jego odpowiedzi miała cechy ironii 
sokratycznej, gdyż premier poszukiwał prawdy odnośnie do poszczególnych zarzutów.

Zatem wyznacznikiem postawy ironicznej była sprzeczność istniejąca między oskarżeniami PiS a rzeczywistą postawą Radosława Sikorskiego. Celem zastosowanej ironii Donalda Tuska jest obrona, ale nie siebie, lecz swojej partii - konkretnie jej reprezentanta Radosława Sikorskiego. Zobrazuje to następujący cytat:

[...], tym bardziej że, jak Państwo się domyślacie, minister Sikorski, co wynika też ze zdarzeń w ostatnich dniach, naszych komentarzy, realizuje w sposób konsekwentny politykę rządu nie tylko od miesiąca czy dwóch, ale od pięciu lat. To chciałbym podkreślić z całą stanowczością, że dzisiaj wotum nieufności wobec ministra Sikorskiego nie jest wotum nieufności wobec polityki czy działań któregoś z ministrów, tylko jest zgłoszonym przez Prawo i Sprawiedliwość wotum nieufności wobec polityki zagranicznej rządu Rzeczpospolitej, konsekwentnie realizowanej nie od dwóch miesięcy czy od miesiąca, ale od pięciu lat. [...] Jeszcze żaden z ministrów nie był tak szybko zgłaszany do wotum nieufności.

Słowa kierują uwagę słuchających na długość czasową realizowanej przez Radosława Sikorskiego polityki zagranicznej na tle całej polityki zagranicznej rządu Rzeczpospolitej.

Donald Tusk przyjmuje postawę ironiczną, ośmieszając wnioskodawcę, czyli Witolda Waszczykowskiego. Jest to widoczne w następującym fragmencie wypowiedzi:

Ale wystąpienie posła wnioskodawcy pana posła Waszczykowskiego było próbą wyjaśnienia tej zaskakującej, wydawałoby się gorliwości. Ustyszeliśmy w wystąpieniu posła wnioskodawcy różne, bardzo różne powody, dla których PiS postanowił zgłosić to wotum nieufności. Wśród tych oskarżeń znalazły się takie epitety jak brak wyrazistej polityki wobec państwa Sahelu; pragmatyzm, to było chyba najcięższe oskarżenie, że Minister Spraw Zagranicznych Polski jest pragmatykiem. 
Premier udowadnia, iż nie traktuje poważnie treści tych oskarżeń, ani ich autora. Oskarżenia te nie znajdują żadnego odzwierciedlenia i potwierdzenia w rzeczywistości. Kolejne wymieniane przez premiera absurdalne oskarżenia Witolda Waszczykowskiego coraz bardziej go ośmieszają:

Usłyszeliśmy, że Minister Sikorski odpowiada za wynik wyborów w Rosji i za to, że Wschód nie stał się Zachodem. Muszę powiedzieć, że zarówno ja, jako szef rządu, ale też myślę Państwo na tej sali mamy duże oczekiwania wobec Ministra Sikorskiego, biorąc pod uwagę jego talenty, inteligencję i kompetencje, ale żeby Wschód stał się Zachodem, szczerze powiedziawszy, takich oczekiwań nie mieliśmy...

Premier stosuje tutaj uogólnienie, zwracając się do wszystkich zebranych, mówiąc, że nikt z nich nie miał takich „wygórowanych” oczekiwań wobec Ministra Spraw Zagranicznych, z wyjątkiem posłów Prawa i Sprawiedliwości.

W niniejszym przemówieniu mamy do czynienia z większą liczbą ról. Ironistą jest Donald Tusk. Jego postawa jest niespokojna, widać zdenerwowanie, mocno ściska rękoma mównicę, często dotyka swoich notatek, ciało jego się kołysze. Ponadto unika kontaktu wzrokowego, przeważnie jego głowa jest pochylona, patrzy na notatki. Ma nieobecny wyraz twarzy. Ofiarą ironii jest wnioskujący o wotum nieufności dla Ministra Spraw Zagranicznych Witold Waszczykowski. Jest on wyraźnie niespokojny i zakłopotany. Ciało ma spięte, dłonią dotyka kącików ust, ma nieco podniesioną głowę, wzrok bardzo niespokojny, nie zatrzymuje się dłużej na żadnym punkcie. Obserwatorami ironii są zarówno wszyscy posłowie znajdujący się na sali sejmowej, jak i Radosław Sikorski, którego dotyczy temat wystąpienia. Przy słowach Donalda Tuska, zwłaszcza przy tych obnażających absurdalność zarzutów Witolda Waszczykowskiego, z sali płyną oklaski i śmiechy. Natomiast postawa Radosława Sikorskiego, którego przez krótką chwilę pokazuje kamera, jest poważna i spięta. Poseł siedzi nieruchomo, wyprostowany, nie rusza się. Ma 
nieobecne spojrzenie, patrzy gdzieś przed siebie, oczy lekko zmrużone, wargi zaciśnięte, głowa lekko pochylona, przymyka nerwowo powieki. Jego postawa świadczy o zdenerwowaniu i spięciu.

\subsection{Kaczyński: Możecie się obstawiać policją. My się nie boimy tego referendum}

Jest to wystąpienie prezesa PiS podczas debaty w sprawie referendum emerytalnego. Zgłosił on wniosek o zrealizowanie takiego referendum.

Wyznacznik postawy ironicznej Jarosława Kaczyńskiego może stanowić zabieg ośmieszenia przeciwników politycznych, chęć zwrócenia uwagi na źle prowadzoną politykę i stworzenie takiego systemu, który okrada najuboższych, a wzbogaca najbogatszych. Stanowi ona w pewnym sensie wyjaśnienie dla celowości zorganizowania takiego referendum:

To Wy ogromnie zwiększyliście deficyt, bezrozumnie rozrzucając pieniądze. Zamiast adresowych pakietów [niezrozumiałe słowo - dop. E.S.], zastosowaliście to właśnie rozrzucanie. Dzisiaj trzeba za to płacić. I oczywiście już co raz co najmniej trzeci w historii tych 22 lat, trzeba płacić z kieszeni średnich i płytkich. Otóż to referendum ma także głębszy sens. To jest referendum odnoszące się do tego, czy ten system, gdzie kieszenie jednych są bronione jak niepodległość, a inne nieustannie drenowane, ma być podtrzymywany. My jesteśmy za zmianą tego systemu. Jest to system skrajnie nieefektywny pod każdym względem. To jest skrajnie nieefektywny, zabijający wręcz naród system społeczny. To jest system po prostu antynarodowy. To jest system, który przynosi korzyści wąskiej grupie, zresztą spod ciemnej gwiazdy. Wy tego systemu bronicie, to jest główne zadanie Waszej partii. Ale my jesteśmy przeciw. Ten system dożywa już swoich dni. My jesteśmy o tym przekonani. To referendum będzie w istocie również nad tym systemem.

Dalej ironizuje na temat możliwości, jakie partii rządzącej w danym momencie pozostały. Jednakże, jego zdaniem, one już nie pomogą: 
Ja wiem, że Wy teraz możecie się tu obstawić policją. Możecie tu armatki wodne poustawiać... tak, tak, widziałem je sam. Możecie się bać i macie powód się bać. I rzeczywiście przyjdzie czas, w którym okaże się, jak ten strach był uzasadniony.

Dokonując porównania siebie i swoich przeciwników politycznych, w lepszym świetle stawia siebie i swoją partię, kieruje się poczuciem wyższości:

Boicie się, ale my się nie boimy. Nie boimy się, ani tych, którzy tam stoją. Nie boimy się tych, których tu nie wpuszczono. I nie boimy się tego referendum. Jesteśmy za Polską, która się będzie rozwijała.

Ironistą jest tutaj Jarosław Kaczyński. Cechuje go niespokojna postawa, kręci się, wymachuje i rozkłada ręce, wzrokiem obiega całą salę. Wydaje się przeżywać swoje wystąpienie całym ciałem. O ofiarach ironii wiadomo tylko tyle, że jest to partia Donalda Tuska. Jednakże kamera prawie cały czas skupiona jest na prezesie PiS. Kilka razy pokazana została z góry sala sejmowa, aczkolwiek trudno z takiego ujęcia coś zaobserwować. Obserwatorami ironii są wszystkie osoby zgromadzone na sali. Przy przemówieniu Jarosława Kaczyńskiego słychać oklaski, śmiechy. Zaś na koniec wystąpienia, kiedy lider PiS schodził z mównicy, większość osób biła brawa na stojąco. Reakcje te są obliczone na wzmocnienie pozycji ironisty i jego narracji.

\section{Opis zachowań niewerbalnych}

Analiza zachowań niewerbalnych została dokonana ze względu na identyfikację reakcji emocjonalnych towarzyszących postawom ironicznym poszczególnych postaci znajdujących się na sali sejmowej. Wyróżniono następujące role odgrywane 
przez polityków: ironisty, ofiary ironii, obserwatorów ironii. Ironistami w analizowanych filmach byli Donald Tusk (przewodniczący PO) oraz Jarosław Kaczyński (przewodniczący PiS). Można zauważyć, iż premiera cechowała postawa spokojna, sztywna, głowę miał zwróconą przed siebie lub w stronę przeciwnika politycznego, gdy kierował do niego słowa. Często przy wymienianiu pewnych słów odliczał je na palcach w powietrzu lub uderzał dłonią o blat. Ręce przeważnie trzymał oparte o mównicę, w chwilach widocznego zdenerwowania ściskał swoje notatki. Postawa Jarosława Kaczyńskiego często była niespokojna, rozkładał ręce i wymachiwał nimi, głowę miał skierowaną w stronę przeciwnika politycznego. Również udawał zdziwienie, marszczył brwi, przeżywał swoje wystąpienie całym ciałem. Zarówno Donald Tusk, jak i Jarosław Kaczyński uśmiechali się delikatnie przy wypowiadanych przez siebie słowach ironicznych.

Ofiarami ironii stawali się odpowiednio Donald Tusk i Jarosław Kaczyński, w zależności od tego, który z nich w danym momencie się wypowiadał, a w przypadku jednego z filmów (Donald Tusk: Debata o polskiej polityce zagranicznej de facto odbyła się w godzinach...) - Witold Waszczykowski. Znaczące różnice w postawie zaobserwowano między Donaldem Tuskiem, Jarosławem Kaczyńskim a Witoldem Waszczykowskim. Postawa pierwszych dwóch polityków była sztywna, niezmienna, ich twarze nie wyrażały żadnych emocji, były skupione na słuchaniu, spojrzenia mieli nieobecne, skoncentrowane na jednym punkcie. Natomiast postawa Witolda Waszczykowskiego była niespokojna, wyrażała zakłopotanie (zawstydzenie), polityk miał spięte ciało, głowę podniesioną, rozbiegany wzrok. Typowymi oznakami zakłopotania (lekkiej formy wstydu) w ujęciu E. Goffmana są: zaczerwienienie, jąkanie, niski bądź piskliwy oraz drżący głos, pocenie się, bladość, mruganie oczami, drżenie dłoni, niepewne ruchy, roztargnienie i przejęzyczenia 
(Goffman 2006: 97; zob. także: Retzinger, Scheff 2000: 84). Witold Waszczykowski przejawiał pewne symptomy zakłopotania, które wynikały z reakcji na zastosowaną przez Donalda Tuska ironię. Ofiary ironii doznają gwałtownego zakłopotania, które pojawia się w momencie zaistnienia ironii i trwa do końca interakcji. Takie nagłe zakłopotanie jest przeżywane bardziej intensywnie niż odczuwane w toku całej interakcji skrępowanie, które sprowadza się do ledwie odczuwalnego podenerwowania (Goffman 2006: 100). Co istotne, analiza wystąpień, wypowiedzi, jak i reakcji emocjonalnych na zastosowaną przez przeciwnika ironię pozwala zauważyć, iż Donald Tusk i Jarosław Kaczyński są wytrawnymi wykonawcami roli, potrafią się uczyć i przygotować do roli, którą mają odegrać. Umieją kontrolować emocje, odczuwają potrzebę zdobycia uznania u widzów (Goffman 2008: 278). Dobrze „wyszkoleni” politycy mają tendencję do ukrywania swoich emocji, ich wystąpienia są zaplanowanym działaniem ujętym w normatywne ramy strategii politycznej. W swoich wystąpieniach często odwołują się natomiast do emocji słuchaczy, przy czym wykorzystują tutaj sugestie, aluzje, metafory, czy właśnie ironię (Krawczyk-Antońska 2013: 63-64). Należy mieć na uwadze, iż opis reakcji emocjonalnych ofiar ironii jest niepełny, gdyż kamera głównie skupiała się na mówcy, nie na osobie, której dotyczyła przemowa.

Reakcje obserwatorów ironii były dwojakiego rodzaju. Po pierwsze, były to reakcje pozytywne, jak brawa, radość, okazywanie rozbawienia w przypadku przemawiania przywódcy ich partii. W widoczny sposób wzmacniały one słowa ironisty. Natomiast w sytuacji, gdy obserwatorzy należeli do przeciwników politycznych ironisty, ich reakcje były negatywne, np. buczenie, podniesione, zdenerwowane głosy sprzeciwu. Analiza reakcji emocjonalnych obserwatorów ironii pozwala stwierdzić, iż częściej słychać pozytywne reakcje sympatyków ironistów niż ich przeciwników. 


\section{Podsumowanie}

Jak słusznie zauważa E. Kołodziejek, język polityczny kształtuje się podczas dyskusji sejmowej. Brak jest wielkich wystąpień, przemówień, referatów i odczytów. Należy również dostrzec, że język polityczny uległ zmianie. Obecnie jest on wzbogacany różnymi inwektywami, sarkazmem i emocjami. Inwektywą dla E. Kołodziejek są wszelkie zachowania mające na celu obrażenie kogoś, wyśmianie, zlekceważenie. Oprócz obelg, wulgaryzmów, autorka zalicza do nich również wypowiedź ironiczną (Kołodziejek 1994: 70). W jej rozumieniu ironia „może być przejawem drwiny, szyderstwa i sarkazmu; demaskuje pewne rodzaje uczuć, głównie nienawiść, wzgardę, gniew, może też mieć intencję poniżenia odbiorcy" (Kołodziejek 1994: 72). Ironia jest zagadnieniem wielce interesującym, ale trudnym do scharakteryzowania i zanalizowania. Często stosuje się ją zamiennie z sarkazmem, zaś dostarczane przez literaturę przykłady różnic między ironią a sarkazmem nie są oczywiste. Podkreśla się, iż sarkazm jest przejawem ironii, służy do niebezpośredniego wyrażania negatywnych emocji. Natomiast ironii towarzyszy uśmiech, rozbawienie i poczucie wyższości (Łaguna 1984: 28). W retoryce politycznej wskazuje się na postawę ironiczną, która ma na celu zdeprecjonowanie przeciwnika. Wykorzystując ironię, nadawca łatwiej nawiązuje kontakt z odbiorcą, który bywa źródłem humoru. Warunkiem jest obopólna znajomość kontekstu politycznego, bez takowej wiedzy odbiorca nie byłby w stanie rozpoznać ironii (Wrześniewska-Pietrzak 2007: 56). Pomimo iż celem ironii jest zdezawuowanie przeciwnika, ośmieszenie jego poglądów i wizji działania, to niesie ona ze sobą często również duży ładunek humoru (Ożóg 2004: 95).

W analizowanych wystąpieniach wyborczych postawę ironiczną wyrażano głównie poprzez ośmieszanie przeciwnika politycznego. Stosowane argumenty miały charakter okołomerytoryczny, zastosowanie ironii miało na celu zdegradowanie przeciwnika po- 
litycznego poprzez ośmieszenie jego poglądów oraz działań. Tym samym ironia pozbawiała dyskusję racjonalnego charakteru. Deprecjacja politycznego adwersarza przejawiała się w ironicznym ośmieszaniu intencjonalnie dobranych cech osobowościowych przeciwnika bądź wykonywanej przez niego roli zawodowej i politycznej. Donald Tusk zarzucał swojemu oponentowi tchórzostwo i walkę przeciwko najsłabszym (w odniesieniu do Jarosława Kaczyńskiego), a także podważał racjonalność stosowanych przez niego argumentów (w stosunku do Witolda Waszczykowskiego). Jarosław Kaczyński natomiast ironicznie zarzucał Donaldowi Tuskowi brak umiejętności kierowania państwem oraz prowadzenia polityki i wypracowanie takiego systemu, który wzbogaca najbogatszych, a okrada najuboższych.

Sejm jest nie tylko instytucją polityczną, ale i instytucją rytualną, w której funkcjonują określone zasady i procedury determinujące zachowania polityków. Rytualizmy sejmowe ułatwiają komunikację politykom i eksponowanie przynależności do określonej partii, co decyduje o specyficznym dyskursie politycznym (Batko-Tokarz 2008: 79-80; zob. także: Czyżewski, Kowalski, Piotrowski (red.) 2010). Dominującą funkcją języka rytualnego jest funkcja fatyczna. Maleje funkcja informacyjna komunikatu na rzecz pokazania chęci nawiązania kontaktu z odbiorcą i zajmowania czasu w procesie komunikacji (Bralczyk 2001: 47). Jednym z takich rytuałów retoryki politycznej z wykorzystaniem ironii jest tzw. rytuał ośmieszania. Pozwala on na wyznaczanie określonych pozycji, przyjmowanie określonych ról przez uczestników, takich jak: ironista, ofiara ironii, obserwatorzy ironii. Strukturyzuje proces interakcji między politykami. Należy zaznaczyć, iż rytuał ośmieszania to akt słowny wymierzony wobec określonej osoby - tutaj przeciwnika politycznego - mający doprowadzić do „utraty twarzy” przez nią i/lub rozśmieszenia publiczności (Konecki 2007: 58-60). Pojęciu „twarzy”, którą posiada osoba pełniąca określoną rolę, E. Goffman przypisywał pozytywną wartość 
społeczną. Jest to obraz własnego ,ja” ukształtowany przez atrybuty społeczne. To, czy osoba ma lub zachowuje twarz, zależy od pełnienia przez nią roli, spójności obrazu „ja” tworzonego w danej sytuacji. E. Goffman wyróżnia trzy poziomy, na których może dojść do zagrożenia twarzy. Po pierwsze, zachodzi to w sytuacji, w której osoba stwarza zagrożenie dla twarzy innych nieświadomie i niecelowo. Po drugie, w sytuacji, w której osoba sprawia wrażenie kogoś działającego złośliwie i celowo. Po trzecie, w sytuacji niezaplanowanej, ale takiej, w której można przewidzieć konsekwencje działania. W analizowanych filmach mamy do czynienia z sytuacją drugiego rodzaju, w której to polityk celowo i świadomie za pomocą ironii stwarza zagrożenie „utraty twarzy” przez swojego przeciwnika. „Utrata twarzy” według E. Goffmana następuje w momencie zawstydzenia danej osoby przez kogoś. Osoba zawstydzona traci kontrolę nad emocjami, a jej twarz ujawnia negatywne emocje. Jednakże w przypadku wyżej analizowanych postaci sceny politycznej, osoba zawstydzona, która padła ofiarą ironii, nie pokazywała żadnych emocji, jej twarz była skupiona, wzrok nieobecny, postawa sztywna i napięta (Goffman 2006: 14). W powyżej analizowanych zachowaniach D. Tuska i J. Kaczyńskiego można zaobserwować następujące wizualne markery wstydu, wyróżnione przez T. Scheffa oraz S. Retzinger (2000: 84), pozwalające na maskowanie zachowań: uciekanie wzrokiem - koncentrowanie się na jednym punkcie, niepatrzenie $\mathrm{w}$ stronę przeciwnika wypowiadającego słowa ironiczne, zaciśnięte usta - skupiona twarz, bez emocji, fałszywy uśmiech - przy wypowiadaniu słów ironicznych. Ponadto, do tego zbioru wyznaczników można dodać werbalne reakcje polityków na wstyd, jakimi były rewanże w postaci ironicznych wypowiedzi na temat przeciwnika. Według E. Goffmana jest wiele technik pozwalających na odzyskanie lub zapobiegnięcie „utracie twarzy”. Jedna $\mathrm{z}$ nich polega na nadaniu zdarzeniu statusu przypadkowego incydentu (Goffman 2006: 15). Ofiary ironii ukrywają emocje, 
banalizują zdarzenie, aby następnie samemu w sposób ironiczny ośmieszyć swojego przeciwnika. Rozśmieszenie publiczności (obserwatorów ironii) natomiast uwarunkowane jest jednym czynnikiem, mianowicie przynależnością partyjną. Zauważona została następująca prawidłowość: jeśli obserwatorzy ironii sympatyzowali z osobą ironizującą, ich reakcją były brawa, śmiech, rozbawienie, które wzmacniały pozycję ironisty; jeśli natomiast obserwatorzy ironii byli politycznymi przeciwnikami osoby ironizującej, wtedy ich reakcje sprowadzały się do okazania wszelkich oznak niezadowolenia (podniesione głosy, buczenie).

Osobę ironizującą cechowało przeważnie poczucie wyższości wobec przeciwnika politycznego - poczucie, że jest ona kimś lepszym. Miało to na celu zdeprecjonowanie przeciwnika w oczach pozostałych. Donald Tusk odwoływał się do kodeksu rycerskiego, według którego główną cechą charakteryzującą polityka powinna być odwaga, walka w obronie najsłabszych. Przejawiała się tutaj ironia retoryczna, mająca na celu zaprezentowanie własnych racji i przekonanie publiczności o ich słuszności. Działo się tak w przypadku oceny zachowania prezesa PiS, któremu zarzucono, że stawał do walki z najsilniejszymi przeciwko najsłabszym, jak i w sytuacji zadawania przez niego pytania „jak żyć?” Natomiast retoryka Jarosława Kaczyńskiego miała raczej charakter oskarżycielski. Zastosowana przez niego ironia była ironią sokratyczną, przejawiała się w poszukiwaniu prawdy, czym jest rycerskość i kto ją przede wszystkim posiada. Była to forma samoobrony.

Analiza wizualna dotyczyła głównie niewerbalnych reakcji emocjonalnych ironistów, ofiar ironii oraz obserwatorów ironii zachodzących podczas stosowania ironii. Wyłoniła ona pewne różnice, jak i podobieństwa w zachowaniach głównych analizowanych postaci sceny politycznej - Donalda Tuska i Jarosława Kaczyńskiego. Różnice można było dostrzec w postawach ironicznych prezentowanych przez obu polityków. Postawa Donalda Tuska była sztywna, raczej niezmienna, spokojna, podczas gdy jego przeciwnika 
politycznego - niespokojna, ruchliwa. Elementem wspólnym w postawie ironicznej u obu polityków był uśmiech przy wypowiadaniu ironii. Podobieństwo dostrzeżono również w postawie polityków, gdy stawali się ofiarami ironii. Cechowała ją niezmienność, usztywnienie, skoncentrowanie na przeciwniku, twarz nie wyrażała żadnych emocji. Reakcje publiczności z kolei były uzależnione od przynależności do poszczególnych partii politycznych.

\title{
IRONIC ATTITUDE OF MAIN ACTORS OF POLITICAL STAGE
}

\begin{abstract}
The aim of the article is an analysis of parliamentary speeches, both the verbal and non-verbal terms of the occurrence of an ironic attitude among the leading political actors. Visual analysis was extremely helpful in order to investigate actions, interactions, interpretative and communication processes, drawing the benefits from the achievements of interpretative and interactionist sociology. Visual analysis was used to describe and interpret emotional reactions of the political scene's leading figures due to the applied irony. For this purpose, the following roles played by politicians in the parliamentary hall were highlighted: ironists, victims of irony and irony observers.
\end{abstract}

Key words: irony, sociology of emotions, political discourse, emotions, interactions, Erving Goffman, rituals ridicule

\section{Bibliografia}

Alleman, Beda (2002), O ironii jako kategorii literackiej, [w:] Michał Głowiński (red.), Ironia, Wydawnictwo Stowa/ obraz terytoria, Gdańsk

Batko-Tokarz, Barbara (2008), Perswazja w dyskursie sejmowym, Wydawnictwo Scriptum, Kraków
Blaszke, Marek (1978), Wartości i normy społeczno-polityczne, [w:] Kazimierz Opałka (red.), Z zagadnień teorii polityki, PWN, Warszawa

Bralczyk, Jerzy (2001), o języku polskiej propagandy politycznej lat siedemdziesiątych, Wydawnictwo Trio, Warszawa 
Bromberek-Dyzman, Katarzyna (2011), Język emocji a język ironii w pragmatyce eksperymentalnej, „Studia z Kognitywistyki i Filozofii Umysłu", 5(1), s. 5-38

Czyżewski, Marek, Sergiusz Kowalski, Andrzej Piotrowski (red.) (2010), Rytualny chaos. Studium dyskursu publicznego, Łośgraf, Warszawa

Doda, Agnieszka (2007), Ironia i ofiara, Wydawnictwo Naukowe UAM, Poznań Głowiński, Michał (2002), Ironia jako akt komunikacyjny, [w:] Michał Głowiński (red.), Ironia, Wydawnictwo Stowa/ obraz terytoria, Gdańsk

Goffman, Erving (2008), Człowiek w teatrze życia codziennego, przet. Helena Datner-Śpiewak, Paweł Śpiewak, Wydawnictwo Aletheia, Warszawa

Goffman, Erving (1987), Gender advertisement, Harper\& Row, New York

Goffman, Erving (2004), Rytuat interakcyjny, przet. Alina Szulżycka, PWN, Warszawa

Graczyk, Piotr (2004), Ironia i kicz jako pojęcie polityczne, [w:] Agnieszka Doda (red.), Powaga ironii, Wydawnictwo Adam Marszałek, Toruń

Kaufer, David S. (2002), Ironia, forma interpretacyjna i teoria znaczenia, [w:] Michał Głowiński (red.), Ironia, Wydawnictwo Stowa/obraz terytoria, Gdańsk

Kołodziejek, Ewa (1994), Językowe środki zwalczania przeciwnika, czyli o inwektywach we wspótczesnych tekstach politycznych, [w:] Janusz Anusiewicz, Bogdan Siciński (red.), Język polityki a wspótczesna kultura polityczna, „Język a Kultura", 11, s. 69-74

Konecki, Krzysztof T. (2007), Nowi pracownicy a kultura organizacyjna przedsiębiorstwa, „Przegląd Socjolo- gii Jakościowej", t. 3, nr 1, Wydawnictwo Uniwersytetu Łódzkiego, Łódź

Konecki, Krzysztof T. (2005), Wizualne wyobrażenia. Główne strategie badawcze w socjologii wizualnej a metodologia teorii ugruntowanej, „Przegląd Socjologii Jakościowej”, t. 1, nr 1, s. 42-63

Krawczyk-Antońska, Żaneta (2013), Pobudzić a zostać pobudzonym. Emocje w polityce, Oficyna Wydawnicza, Katowice

Łaguna, Piotr (1984), Ironia jako postawa i jako wyraz, Wydawnictwo Literackie, Kraków-Wrocław

Łempicka, Zofia, Stanisława Skorupka, Halina Auderska (1969), Maty stownik języka polskiego, Państwowe Wydawnictwo Naukowe, Warszawa

Milkoska-Samul, Kamila (2013), Emocje a skandal polityczny. O sposobach wykorzystania emocji w dyskursie politycznym, „Przegląd Socjologii Jakościowej", t. 9, nr 2, s. 164-183

Muecke, Douglas S. (2002), Ironia: podstawowe klasyfikacje, [w:] Michat Głowiński (red.), Ironia, Wydawnictwo Słowa/obraz terytoria, Gdańsk

Ososiński, Tomasz (2014), Ironia a jednostka. Koncepcje ironii u Friedricha Schlegla i Sokratesa, Wydawnictwo Uniwersytetu Warszawskiego, Warszawa

Ożóg, Kazimierz (2004), Język w służbie polityki: językowy kształt kampanii wyborczych, Wydawnictwo Uniwersytetu Rzeszowskiego, Rzeszów

Passi, Isak (1980), Powaga śmieszności, Państwowe Wydawnictwo Naukowe, Warszawa

Przyłęcki, Paweł (2012), Populizm w polskiej polityce. Analiza dyskursu, Wydawnictwo Sejmowe, Warszawa 


\section{Postawa ironiczna czołowych aktorów sceny politycznej}

Retzinger, Suzanne, Thomas Scheff Wrześniewska-Pietrzak, Marta (2007), (2000), Emotion, alienation, and nar- Wartościowanie jako oręż perswazji, ratives: Resolving intractable conflict, [w:] Piotr Lissewski (red.), Polityka „Mediation Quarterly”, vol. 8, no 1, s. i perswazja, Wydawnictwo Naukowe 71-85

INPiD UAM, Poznań 